\title{
'A Haunting of Ancestors': The Conjuring of Memory in Indigenous South African Poetry
}

\author{
Dr Gerhard Genis \\ Faculty of Education \\ University of Pretoria, South Africa \\ Email: gerhard.genis@up.ac.za \\ Orcid number: https://orcid.org/0000-0002-6097-5681 \\ Doi: https://doi.org/10.46222/pharosjot.102.117
}

\begin{abstract}
This paper focuses on the interaction of language, the physical and psychological body and the environment in creating a conjuring of ancestors in indigenous South African poetry. The 'haunting' of the ancestors is mirrored by the intergenerational word-traces in the indigenous poems. These 'poetic bodies' are laced with word and phrase markers that consist of culturalspecific metonyms, metaphors and archetypes. The poetic bodies are subsequently stringed together by the word-traces that pulsate in the chromosomes and the minds of the progeny. They order the remembrance and re-membrance of the ancestors within a specific culturalhistorical context. Significantly, these 'poetic bodies' are conduits of consciousness that reflect communal practices or archetypes and images of loss and gain.
\end{abstract}

Keywords: Indigenous poetry; Ancestors; Poetic bodies; Intergenerational memory; Remembering.

\section{Introduction}

In this article, I want to indicate how the conceptualisation of 'poetic bodies' may be used to re-member, re-experience and re-constitute instances of ancestral conjuring in indigenous South African poetry. The conceptualisation of the 'poetic bodies' falls within the field of epipoetics, which is the weaving together of various theoretical and philosophical approaches that include poetics, psychoanalysis, bio-cultural studies, archaeological-anthropological approaches, posthumanism, indigeneity theory, epigenetics and neuroscience (Genis, 2020; $2019 ; 2018)$. Poetic bodies is an epistemological and methodological construct that facilitates the summoning of ancestral traces from among the lines and verses of the indigenous poetry. Within these poetic bodies, three acts of meaning construction are closely interwoven: these include verbal and non-verbal language usage; intergenerational memory construction or remembering; and the socio-cultural and historical contextualisation of place. ${ }^{1}$ Poetic bodies provide for a post-humanistic haunted space, where the ancestors are re-membered or conjured in current spaces (Newfield \& Bozalek, 2019, 37). Crucially, indigenous poetic bodies represent a 'poetry of remembering' (Gunner, 1995: 51) and re-membering (Newfield \& Bozalek, 2019: 52).

In this paper, South African indigenous poetry from various eras is conceptualised as 'poetic bodies' to illustrate the inter-generational and multi-sensory 'haunting' or re-membering of memory within a southern African context. For the purposes of this paper, indigeneity is

\footnotetext{
${ }^{1}$ In earlier articles (Genis 2020; 2019), I conceptualised these three acts of meaning making as the Bodily (language), the Inner-Bodily (memory) and the Outer-Bodily (context).
} 
conceptualised as follows: 'Rather than an embodied essence, indigeneity then becomes a site of memory and of struggle, an ongoing commitment, a fluid performative identity under continual negotiation' (Mavhiza \& Prozesky, 2020: 4). Indigeneity is a contested concept, as defining it is an essentialist action in itself, which excludes others. Consequently, this paper agrees with Mavhiza and Prozesky's (2020) 'fluid' conceptualisation, which allows for a constant re-membering and reconceptualization of what being indigenous entails. Indigenous storytelling, literature and poetry are deeply embedded in the collective cultural and psychological consciousness of South Africa (Genis, 2019: 60-61). Therefore, indigenous poetry is part of Indigenous Knowledge, which is, according to Manathunga, Davidow, Williams, Gilbey, Bunda, Raciti, and Stanton (2020: 14) 'Knowledge production ...[that] is always intergenerational and multidirectional across time and space.' Crucially then, indigenous poetry is the traces of ancestral interaction among the indigenous peoples of South Africa $^{2}$ across generations and historical timeframes.

The poems discussed in this article are mostly translations of the original isiXhosa and isiZulu languages. Consequently, there is a danger that 'The real meaning of the poem[s] could... have been lost somewhere in the translation' (Genis, 2018: 155). The question that arises is whether the poetic rhythms, rhymes and nuances of a language could be reproduced in another. Viljoen (2006: 33) states that translations of poetry 'construct new cycles out of existing poems'. She argues convincingly that translations enhance communion between languages and cultures in her discussion of the South African poet, Antjie Krog's Afrikaans renditions of indigenous South African poetry (Viljoen, 2006). Significantly, Viljoen (2006: 38) refers to the izibongo or indigenous oral praise poems as being constantly recreated or remembered by the audience through their sensory responses to the unique spoken renderings by poets. The translations by scholars and poets - which include Jack Cope, C.M. Mcanyangwa, Jeff Opland and Abner Nyamende - of the poems quoted in this article are part of this perpetual process of creating 'new cycles' of representing and re-membering poetic bodies. These metamorphoses of meanings through translations should not be viewed as destroyers of 'real' meaning, but as representations or 're-memberers' of the same poetic bodies dressed in a myriad of linguistic and cultural fabric.

These indigenous poetic bodies, which include indigenous poetry and praises or izibongo consist of units-of-meaning or praise-units. The 'facts' or izinto that the imbongi or poet provides or channels about the ancestors are instances of the same ibali or oral history tradition, which may undergo textual changes in the process of intergenerational oral transmission. Subsequently, indigenous history, literature and folktales become a matrix of interchangeable and expandable limbs of meaning, which are detached and re-membered or re-attached to the textual body that constitutes the praise poem (Opland, 1992: 198; Opland, 2009: 9-12, 20-23), i.e. the poetic body. The subject or subjects of the izibongo are the focus of its meaning, and not its coherent structure; the subject, together with its adjectival praiseattachments, is constantly relocated within the structure of the poem, depending on the nature of the oral performance. Crucially, this subject may be objects, animals, commoners or royal personages (Opland, 1992; Opland, 2009: 7-8).

These apotheosised marionette bodies that are strung up with word-strands are, however, not merely soulless and lifeless traces of history. Newfield and Bozalek (2019: 50) hold that 'Writing is ... a bodily and a spiritual action', and Lo Liyong (2018) asserts that indigenous literature is animistic traces and that it has a soul and memory within a body. The following section explains or 'conjures' the conceptual skeleton for poetic bodies, and indicates how the indigenous poet acts as a spiritual marionettist.

\footnotetext{
${ }^{2}$ For the purposes of this article, indigenous peoples refer to those whose ancestors and cultures are intergenerationally immersed in the South African soil.
} 


\section{Poetic bodies as sites/portals for conjuring}

The poetic body is a conduit for the conjuring of memory and re-membering through the art of storytelling within a specific context and place. Manathunga, et al. (2020: 7) state that 'First Nations peoples [indigenous peoples] around the globe have used rhythms of sounds and words to form the basis of oral information transmission for thousands of years.' Similarly, in southern Africa, the stone-age San have told stories and danced round communal fires for millennia. These stories and dances expressed the San's cosmology and ontology. These embodied stories progressed to poetic renditions of social relationships, the rocks, insects, and predators of the veld, the moon and stars of the sky, and wars and colonial contact (Krog, 2004). The telling of these stories was sometimes accompanied by rock painting (LewisWilliams, 2004a). Lewis-Williams (2004a) has argued that there is a close connection between the act of conjuring the ancestors and the creation of art through a universally-held neuropsychological hallucinatory experience. Boiling ${ }^{3}$ or 'making' art and poetry rewires the nervous system in altered states of consciousness (Lewis-Williams, 2004a: 101-162; 2004b: 47-48, 55-61). Through hallucinations, the San shamans were able to commune with the spirit world below and above in ensuring ancestral protection and sanction by relaying the ancestors' wishes to the progeny. These ancestor-sorcerers were consulted because of the advice they could give on everyday things including medicinal and social-hunting practices (Van der Post, 1961; Lewis-Williams, 2004a \& 2004b).

Similarly, the rich South African indigenous oral poetic tradition, which was first penned during the nineteenth century, also served as a multi-sensory verbal portal between the ancestors and the progeny (Opland, 2004). Ndlovu (2020: 17) indicates that 'The indigenous poetry tradition of izimbongi, connected to ancestral channelling as much as they craft oral history and praise, are very much alive in South Africa'. Therefore, like the San shamans, the indigenous poets served and serve as vessels through which the ancestors made and make their wishes known to the living (Ndlovu, 2020: 16).

Both the 'boiling' of the San shamans and the word-contemplations of the indigenous poets are characterised by deep thinking and word-meditations. The San shaman progressed through a three-stage hallucinatory experience whereby the senses transcend or ascend into an altered reality with concomitant instances of outer-bodily or metamorphosed bodily experiences (Lewis-Williams 2004b: 56-57, 60-61). Similarly, indigenous poetry uses voice and dance/movement/music to create a haunted space for coming together or re-membering through 'deep listening' (Manathunga et al., 2020: 7-8). Similar to Ndlovu (2020: 12-13), Manathunga et al. (2020) argue that 'deep listening/listening with the heart' forms part of the indigenous poetic experience.

The sensory quality of these 'deep listening' and word-meditations is unequivocal. D'Abdon (2016) agrees with Ndlovu (2020) and Manathunga et al. (2020) that indigenous poetry, which includes spoken-word poetry, is the multi-sensory expression of experience and memory. It is the oral and emotional voice meeting and enlivening the written word. Crucially, spoken word poetry frees the poetic energy from the page (D'Abdon, 2016: 46). The tradition of 'speaking' poetry or spoken-word poetry is closely connected to a bodily process of spiritual becoming: 'The spoken word poet's "emotional rhythm" springs from inside his/her body, and the voice is its audible extension, the vital force which resuscitates words trapped on the printed page' (D'Abdon 2016: 46). The spoken word poetry serves a 'cathartic effect' in live and alive spaces where these poems are spoken (D'Abdon, 2016: 47). In effect, it lifts or raises the ancestral voices or spirits from dead pages. The imbongi or poet becomes a word-shaman, who, through 'boiling' speaks in the voice of the ancestors through the act of poetic conjuring.

Within the South African context, SEK Mqhayi (1875-1945) was a 'boiler' or conjurer of note. Mqhayi was the most eminent and prolific Xhosa imbongi or indigenous poet of the first half of

\footnotetext{
${ }^{3} \mathrm{~A}$ word denoting trance or hallucination in the spiritual framework of the San.
} 
the twentieth century. He published biography, poetry, fiction and history (Opland, 2007: 105; Opland 2009). He wrote in Xhosa within the imbongi tradition, but was influenced by European texts, including the English Bible (Opland, 2009: 14, 15, 22). His spoken word poetic conjuring of the ancestors led to his audiences' spiritual revival and to his own personal ecstasy, as the following eyewitness accounts attest:

\begin{abstract}
With these words the Nation's Poet boils our blood and enflames our ears so we cannot hear. (The Bantu World, 9 March 1940; Opland, 2009: 9, 526)

When he spoke this last word, he dropped his head to his chest. We rose to our feet, clapping and cheering. I did not want ever to stop applauding. I felt such intense pride at that point, not as an African, but as a Xhosa; I felt like one of the chosen people. (Nelson Mandela, former President of South Africa, quoted in Opland, 2009: 9)
\end{abstract}

These are among the 'numerous examples of how indigenous music, song, dance and storytelling serve as medicine, reinforcing people's direct connection to the Earth [their ancestral culture] along with its variety of natural medicines and the therapeutic, sacred or ritual [real and psychological] spaces the [ancestral] land provides" (Ndlovu, 2020: 15-16). Ndlovu (2020: 18) further attests to this close bond between the poetic word and the space or context in which it is heard: 'this word-sound element of indigenous expression can also be understood as channelling emotion and energy within the space'. This 'space' refers to the physical site where the poetic words are spoken and to the ancestral world that the poet conjures. Manathunga et al. (2020: 13-14) also refer to the First Nations' close bond with the land of the ancestors in an indigenous Australian context. Land, 'Country' and place saturate the First Nation's state of being in a constant cycle of becoming. Similarly, in an indigenous South African cosmology, the dead, who inhabit the land and the past, are integrated into the world-of-experience of the living. The quick and the dead are conceptualised as one communal body that shares mutual social-environmental responsibilities (Zarwan, 1976: 523; Peires, 1981: 161-167; Peires, 1987: 45, 48, 56; Schoeman, n.d.: 452-453).

Indigenous South Africans view time, space and action as cyclic. The ancestral world (the past) is intertwined with that of the living in the present and future (Mda, 2000). This cyclic nature of existence, which incorporates the world of the ancestors, is re-membered in the indigenous poetry (Genis, 2018). The praises of the imbongi coalesce into aural, visual, tactile and representational patterns, similar to the geometric rock paintings of the San: both depict a 'deep listening' or spiritual and emotional connection to the ancestors and the land, and to the visions that lie beyond the page and behind the rock. Crucially, the imbongi serves as conjurer and ventriloquizes the ancestors. She does this through praise-units to re-member aural, aerial and visual representations of the spirits (Genis, 2018: 131-184).

In Jungian terms, the unconscious is part of 'the mythic land of the dead, the land of the ancestors' (Jung, 1961: 233-234); it represents Jung's 'the collectivity of the dead [and living souls]' (233-234), as all bodies, living and dead, are part of the 'collective spirit' (116) - an assemblage of Thespians (116-117). Consequently, to Jung, writing is a spiritual conjuring of memory and the ancestors: 'Then it began to flow out of me, and in the course of the three evenings the thing [The Septem Sermones] was written. As soon as I took up the pen, the whole ghostly assemblage [of spirits] evaporated. The room quieted and the atmosphere cleared. The haunting was over' (Jung, 1961: 232-233). Similarly, the imbongi conjures and channels this 'collective spirit' of the 'land of the dead' through her spoken-word poetry.

The ancestral world or the home of the spirits in the southern African milieu includes the SanTswana's 'Slippery Hills' in Botswana, (Van der Post, 1958: 174-200; 1961: 158). The Basotho view the hole with its overhanging hill at Ntsuanatsatsi in the Free State, as the place where the first Basotho were born, and where their voices can still be heard (Hall, 1987: 48). The Xhosa believed that the marsh uHlanga was the birthplace of people and cattle. This water 
metaphor includes the birth of a Christ-like saviour Sifuba-sibanzi. (Peires, 1987: 54-55, 6163).

Significantly, the indigenous poetry and songs constituted a portal through which these places of creation could be accessed and from where the ancestors could be conjured through the deep word-meditations. According to Hodge (1998: 31), the bio-psychological body is 'a system of inscription'. The words of the ancestors are inscribed on the body through memory, which is 'the retrieval of a past into the present, suggesting a cyclical motion to time, from event, to forgetting, to retrieval', i.e. 'remembering' Hodge (1998: 38). Indigenous poetry, history and folklore are all mirror-images of the same immortal bodies caught in a perpetual cycle of texts, poets and oral performances, giving voice to warriors, kings, commoners and ancestors. In the indigenous South African poetry, these poetic bodies are inscribed with the multi-sensory and all-consuming 'Ahom' of re-membering.

\section{Poetic bodies as sites of re-membering: the great 'Ahom'.}

\begin{tabular}{|c|c|c|}
\hline $\begin{array}{l}\text { Respond! Respond! You are called to } \\
\text { heaven. } \\
\text { Come, all you multitudes! Come, all you } \\
\text { children! } \\
\text { Ahom, ahom, ahom, ahom, ahom. } \\
\text { It has been fenced in and surrounded, this } \\
\text { land of your fathers. } \\
\text { He who responds to the call will be blessed. } \\
\text { Ahom, ahom, ahom, ahom, ahom. } \\
\text { Sele! Sele! } \\
\text { Ahom, ahom, ahom! } \\
\text { Respond! Respond! You are called to } \\
\text { heaven. } \\
\text { Ahom, ahom, ahom, ahom, ahom. } \\
\text { (Ntsikana, Ntsikana's bell; Opland, 1992: } \\
\text { 109; tr. Xhosa) }\end{array}$ & $\begin{array}{l}\text { Ele, le, le homma } \\
\text { Ele, le, le hom } \\
\text { Chorus: } \\
\text { Ahom, homna, hom, homna! } \\
\text { Hom, homna, hom, hom! } \\
\text { It was proclaimed at Gqorha } \\
\text { And at the Lake of Arms } \\
\text { It was proclaimed at Gaga } \\
\text { And at Mankazana } \\
\text { It came to speak } \\
\text { Ele, le, le homna } \\
\text { Ntsikana, Round hymn; Opla } \\
\text { tr. Xhosa) }\end{array}$ & $\begin{array}{l}\text { Hom, homna! } \\
\text { Hom, hom! } \\
\text { Hom, homna! } \\
\text { Hom, hom! } \\
\text { Hom, homna! } \\
\text { Hom, hom! } \\
\text { and, 1992: 110; }\end{array}$ \\
\hline
\end{tabular}

In the early-nineteenth century indigenous songs/poems, Ntsikana's bell and Round hymn, Ntsikana (c1780-1821), the Xhosa preacher, invokes his people to prayer. In these poetic prayers, the 'Ahom', and 'Hom, homna' are repeated as an amen-mantra in the calling out to God's children. Ntskikana was an early Christian convert who preached the Word of God. This diviner had established a Christian community in the Eastern Cape before the white missionaries erected their mission stations (Opland, 1992: 109-112). Ntsikana's, Ntsikana's bell, Round hymn and Great hymn, another izibongo praising God, have permeated the Xhosa religious consciousness. Ntsikana's disciples were the inheritors and exponents of a nascent African literature in South Africa (Opland, 1992: 111-112; Opland, 2004: 31-32).

The 'Ahom', the ringing of (h)allelujahs and Amen, has deep roots in the Xhosa collective unconscious and psyche. It has been tolling since the first singing of Ntsikana's early nineteenth-century poetry-hymns. These hymns have persisted as popular and influential choral church music to this day (Opland, 1992: 109-112). These are still ringing today in the 
indigenous poetry, in Michael Huna's 'modern' poem The death of Ntsikana (Butler \& Opland, 1989: 87-89), and in Guy Butler's Ntsikana's bell (Chapman, 2002: 144-147).

Significantly, Ntsikana is no mere lackey of white religious imperialism. As an imbongi, he remembers or reconstitutes the western God within the Xhosa cosmology. He assigns God the status of a traditional Xhosa chief and ancestor through praise poetry:

See! there's the Creator of Life, he of the school.

See! there's the Creator of Life, he who calls us to rise,

See! there's the Creator of Life, he has arisen on high.

(Ntsikana, Dalibom; Opland, 1992: 110; tr. Xhosa)

The mantra of the creator rings out three times in this izibongo; this represents the perfect unity of the Trinity in the Bible. Ntsikana re-members the 'mysterious Word', the God-particle of St. John's Gospel (Holy Bible). This invocation led to the epiphany of St. Paul on the road to Damascus, which is similar to Ntsikana's conversion to Christianity (Opland, 1992: 109). It also refers to the all-encompassing 'Flash' of Kristeva's 'Word Flesh' (Kristeva, 1986). Ntsikana's poetic bodies are regenerators and a re-membering of meaning and memory. It was only through concrete language that the abjected corpse of the ancestor could be 'remembered', bit by bit - fleshed out by words, and made 'WORD FLESH':

Let a body venture at last out of its shelter, take a chance with meaning under a veil of words. WORD FLESH. From one to the other, eternally, broken up visions, metaphors of the invisible. (Kristeva, 1986: 162)

These poetic bodies serve as conduits or mediums through which the ancestors are invoked. The act of performing and writing becomes a perpetual cycle of a 'writing-into-existence', as the amabali's or izibongo's subjects - people, places, objects, nature and animals - are part of the memory of the living, part of those who must still be born, and part of those who have already gone to the ancestral home. The poetry becomes the dream: dreaming the ancestors (Van der Post, 1961: 151). ${ }^{4}$ The imbongi's oral performance emotionally explodes and boils over into a trance-like state through which the performer is transported to the past by invoking the ancestors in a torrent of word-sacrifices to placate the gods and spirits (Opland, 1992: 26$27,106-108,181,186,225)$. This cry from the grave is a very potent force:

$$
\begin{aligned}
& \text { We hear the loud call } \\
& \text { you see with your eyes. } \\
& \text { We hear the buzzing } \\
& \text { You make in heaven. } \\
& \text { Always think of this world } \\
& \text { in the joy of that world; } \\
& \text { recall what you left behind } \\
& \text { and inform the ancestors }
\end{aligned}
$$

(SEK Mqhayi, Umfi u Jonas Ntsiko (1918) / The late Jonas Ntsiko; Opland, 2009: 146; 148; author's italics)

Jonas Ntsiko, the ancestor, communes and communicates with his progeny through voice and sight. He is re-called and re-membered by the imbongi, SEK Mqhayi. Similarly, in a praise poem dedicated to the Xhosa writer and politician J.T. Jabavu (1859-1921), Mqhayi writes:

\footnotetext{
${ }^{4}$ The Kalahari San told Laurens van der Post that '"there is a dream dreaming us'".
} 
You will not die, you'll keep speaking -

your reports are written in books,

written in Imvo Zabantsundu's lines.

Your reports are written in books -

written in the minds of those who've been born.

Your reports are written in books -

written in the hearts of those who die.

Your reports are written in books -

written in the minds of your nation.

Go and rest when your Lord so commands -

we who remain will interpret our dreams of you.

(Umfi u J.T. Jabavu (1921) / The late J.T. Jabavu; Opland, 2009: 158; author's italics)

The imbongi re-writes the reports of the ancestor in the hearts and minds of the progeny. Mqhayi serves as the interpreter of the ancestor's dreams: he is dreaming the ancestral dream.

However, the imbongi also reports on colonial subjugation and the loss of ancestral land. In Ntsikana's bell, Ntsikana refers to the land of the Xhosa that was being 'fenced in and surrounded, this land of your fathers' by the colonisers. His poetic word-prayers foreshadow the decimation of the lands of the Xhosa and other indigenous South African communities through wars of colonial conquest. The Xhosa were finally subjugated by the colonial authorities during the Ngcayechibi War of 1878-79 (Opland, 2007: 89). All indigenous communities had lost their independence through economic, religious and martial colonialism by the turn of the twentieth century. This loss represented a loud ' $O$ ' cry of nothingness. Therefore, this fleshing-out of the word is not only a re-membering of the black socio-culturalpolitical body, but also a desperate battle cry, which reverberates through the indigenous poetry and songs of the nineteenth and twentieth centuries. Ntsikana's 'Ahem' is echoed in the 'Hum', and the 'Ow', 'Oh', 'O', 'Ah', 'Alas' and 'Nada' that haunt the body of indigenous poetry on the re-membering of wartime loss (Genis, 2018: 167-184).

Weep on, O, ye loved ones; yet tears are in vain!

We never shall march in the sunlight again!

$[\ldots]$

O, Chaka! Where art thou? We call thee in vain!

Thy kraal of the Blest in this Valley of Pain?

The brave ones, our sires, who fell long ago.

Where are they, O Great One, thy children would know?

O, take us, enrol us, we wait, King, for thee!

To march in thine impis, 'thy warriors to be!

(The spirit song of Mehlokazulu, AEK, Ilanga Lase Natal, 29 June

1906; Couzens \& Patel, 1991: 38-39)

This poem refers to the 1906 revolt by Bambatha, the chief of the Zondi-Zulu tribe. They were opposed to colonial taxation, and the colonial treason trial of Dinuzulu, the successor to the 
Zulu throne (Maylam, 1989: 141). Bambatha's rebellion was a final effort by a traditional leader in South Africa to throw off one of the many yokes of colonialism (Saunders \& Southey, 2001: 17). The demise of the Zulu royal house led to a potent rallying cry harking back to Shaka's glory days in the time of Zulu independence. AEK's izibongo succinctly captures this spirit of revolt. The imbongi re-members and calls on King Shaka to lead the Zulu for one final time. The repetitive cry of ' $O$ ' foregrounds the fact that the Zulu will never again regain their former glory under King Shaka's rule of the early nineteenth century. Bambatha was beheaded after his defeat at the battle of Mome Gorge. Later, his head was mounted on a wooden frame in London and returned to South Africa (Genis, 2018: 140). This barbarous act by the colonial Natal government represented the ultimate loss, or ' $O$ ', which signifies nothingness: in an indigenous context, a body has to be buried in ancestral land, where offerings are made by the family. If this bond with the ancestral land is broken, divine displeasure is visited on the perpetrators (Schoeman, n.d.: 452). Bambatha's headless body represents a de-membered ancestor.

The ' $O$ ' prayer to the ancestors also represents a cry of sedition in the indigenous poetry. In the izibongo, The prince of Britain, Mqhayi 'praises' Edward, the Prince of Wales, who visited South Africa in 1925, as the treacherous colonising monster, Gilikankqo:

Hayi, the mighty Great Britain!

Here she comes with bible and bottle,

Here she comes, a missionary escorted by a soldier,

with gunpowder and guns,

with cannons and breechloader.

Forgive me, O Father, but which of these must we accept?

Pass on, calf of the beast,

Trampler who even now is trampling,

Pass on and return safely - eater of our country's inheritance.

Long live the king!

(The prince of Britain [royal visit, 1925], S.E.K. Mqhayi; tr. Xhosa; Chapman, 2002: 65-67)

Similarly, in the izibongo, The black army, Mqhayi 'praises' the 'King of England' in subversive terms:

Oh yes, we are so thankful

When our homeland gives us a thought

And has us go down to the coast to work

In the hour of its difficulty.

And in any case, who are we

To be able to help the King of England,

The noble gentleman on whom the sun never sets

Who holds his sway over the land and sea

And thinks even of annexing the heavens.

(The black army, vii, 1916; Cope \& Krige, 1968: 276) 
The imbongi alludes to the fact that the British government required black help in winning the war against Germany during the First World War: 'They reached their last resort in calling you' (vii, 278). Mqhayi employs seditious irony: the superior white man needed the inferior black man's assistance on the battlefield to defeat other white men. In these instances, the izibongo were used to blame, shame and attack, and not to praise (Opland, 1992; Gunner 2002: 213).

The First World War battlefields became a space where the heroic bull-calves or young black soldiers, became exalted ancestors themselves (Genis, 2018: 131-185). The SS Mendi was a troopship that transported African soldiers of the South African Native Labour Contingent to France when it was struck by the transport ship SS Darro on 21 February 1917. It sank in the English Channel near the Isle of Wight with more than 600 mostly black soldiers on board (Grundlingh, 2011: 20):

Ah, those dead stood in the foremost rank

Of Africa - great the ship's burden when she sank.

Brave of the brave they were, men who bring

With their blood greetings to the King of Kings.

Death has its wage - to live again.

Gladly I would stand with them, new-risen men,

And shine like one whose work is well done

In the great brightness of that Day's dawn.

So then, let it be.

(SEK Mqhayi, The Sinking of the Mendi, vi, 1917; Cope and Krige, 1968: 278-280)

The bull-calf became a powerful metaphor for the physical prowess of the African soldier. Cattle were and are central to the African's social, economic and spiritual existence. ${ }^{5}$ The bull also has a military significance; it is a potent indigenous archetype for battlefield prowess:

Gouger!

Stab-on-sight!

Horn quick to gore.

Crusher with the haft of an axe:

It's a sad day for those you stab,

Like one who gives then takes.

Bull with many scars.

One who bellows and the cowards scatter.

(Bull, tr. Zulu; Opland, 1992: 160)

Importantly, these bull-calves, even though they lay in a far-off and strange watery grave, their heroism has re-interned them in the ancestral world. They are 'new-risen men', not dead, but conjured through their praise poems in metaphors of the divinely conceived and sacrificed bull-calves. Significantly, the Mendi bride had re-claimed them through a sacrificial rebirth:

\footnotetext{
${ }^{5}$ During traditional marriages, cattle are given as a gift to the parents of the bride to compensate for the loss of their daughter. Cattle are also the symbol of wealth and status in African communities and sacrificed to appease the ancestors (Coertze, 1960).
} 
And as our bride down her last flood

The Mendi takes the service of our blood...

Black men of our blood, we said this thing -

'On that far-off field you are our offering'...

Do we not sacrifice the bull-calves of the kraal...

Death has its wage - to live again.

(SEK Mqhayi, The Sinking of the Mendi, 1917; Cope \& Krige, 1968: 278-280)

The regenerative quality of water is evident in the marrying and birthing of the bull-calves through the water-entombed Mendi bride. Water, therefore, is a space in and through which the ancestors may be conjured. Dxui, 'the first spirit of Africa', is an ancient manifestation of water as a site of spiritual birth (Van der Post, 1961: 154, 199-200). As stated earlier, the Xhosa believed that a marsh, uHlanga, served as the womb for people and animals; the water metaphor also encompassed the birth of a Christ-like saviour Sifuba-sibanzi during the Xhosa cattle-killing of the 1850s (Peires, 1987: 54-55, 61-63). Additionally, water represented the baptismal font of the missionary schools, where so many Xhosa elite, including Mqhayi, received a western education. Significantly, the amathongo / izi(imi)nyanya (ancestors) and Christ all emerged from a watery source. The Zulu also saw water and the sea as a place of 'wonders', 'mystery' and 'a purge for bathing and for drinking' (Zulu song, early 20th century; Tracey, 1948: 71). Xhosa and Zulu soldiers bathed in the sea and rivers during cleansing ceremonies, which were accompanied by war songs (Opland, 1992: 132; Genis, 2018: 160).

The imbongi, J.J.R. Jolobe (1902-1976) mystically refashions this watery expanse of rebirth in his izibongo, The cattle-killing. He conjures the prophetess, Nongqawuse's water-bound vision of the ancestors:

The rays of the morning are breath-taking,

Creating a shimmering glitter

On the stretch of water,

Surrounded by beautiful flowers

As if by watchmen,

And a cluster of reeds

Where the songsters nest,

A riot of colours

Taking in the breeze

Of heavenly breath,

Dancing in rhythm

As if entranced in praise

On that expanse of water,

The ancestral spirits' home.

(Butler \& Opland, 1989: 56; tr. Xhosa)

However, Jolobe's poem ends with an apostrophic lament, in which the sea/water is depicted as a site of loss: 'Thou, O cascading falls, / Whose waters drop, / Do your eyelids overflow, / Weeping?' (Butler \& Opland, 1989: 60). It is now a metaphor for the death and destruction 
wrought by the cattle-killing. The Xhosa cattle-killing (1856-57) was a religious-cultural revival movement among the Xhosa, which was initiated by the prophetess, Nongqawuse in response to colonial encroachments on the land of the Xhosa. It included the sacrifice of bewitched cattle and crops, so that the ancestors could return to restore the Xhosa's ancestral lands. However, this only led to the starvation of tens-of-thousands of Xhosa (Peires, 1987).

Water was, therefore, also an archetype for loss; the spilling of water signifies both a spiritualemotional and physical leaking, and the crossover from life to death and the land of the ancestors:

I am spilled out like water

Chorus: Beat the drum, oh yea!

We are finished!

Chorus: Our people are finished!

Oh! to have one's parents dead!

Chorus: Our people are finished!

I am going to the ford where my sister was killed.

( I am spilled out like water, tr. Shangana-Tsonga; Opland, 1992: 140)

The izibongo on the Mendi also represent the destructive power of the water image:

With the sinking of this ship, the Xhosa people lost their reliable sons; but when the name of this chaplain was mentioned among the dead, the nation was dealt a grievous blow. Clearly Xhosa himself suffered a severe wound, a massive loss, at the setting of this brilliant star of his.

Ow!!!

Nojoli's cry was heard,

the keening cry of Rharhabe's wife,

daughter of Nomagwayi of eMbo,

bewailing the beauty swept out to sea,

saying death hadn't claimed them, they were growing in strength!

Peace, Phalo's people,

Ngconde's, Butsolobentonga's.

At times like these a nation despairs.

Chizama's star has set,

the Xhosa nation's back is broken!

The best of stars we took such pride in,

the animal cub died while talking,

died giving heart, securing his testament!

Someone said what an unseemly death,

suddenly coming in alien territory,

in a strait between two bulls.... 
(Mqhayi, The late Rev. Isaac William Wauchope, The Bantu World, 19 January 1935: 4; Opland, 2007: 107, tr. Xhosa)

In this izibongo, Mqhayi re-members the soldier-hero, Wauchope, to lessen the plight of his people and to serve as their encourager. This poem was conceived when black reaction against white colonial rule was stifled by the South African government. In this izibongo, the soldier Isaac William Wauchope (1852-1917), who 'died giving heart', as an African hero, is called upon to lead the First World War warriors on their quest to achieve psychological and political emancipation from colonialism. Wauchope and the bull-calves are great warriorhunters whose souls or hearts have turned into celestial bodies/stars in the sky, according to traditional spiritual belief (Van der Post, 1961). Wauchope was reported to have led a death dance on the Mendi while exhorting his comrades through an izibongo that praised the martial exploits of the African warrior:

\begin{abstract}
Be quiet and calm my countrymen, for what is taking place now is exactly what you came to do. You are going to die, but that is what you came to do. Brothers we are drilling the drill of death. I, a Xhosa, say you are all my brothers. Zulus, Swazis, Pondos, Basutos, we die like brothers. We are the sons of Africa. Raise your cries, brothers, for though they made us leave our weapons at our homes, our voices are left with our bodies. (Jacob Bam; Mendi death-drill, 1936, The new African of 23 March 1936: 23; in Nyamende, 2011: 14).
\end{abstract}

Here the courage of the warrior-ancestors is conjured through word, voice and dance. However, their wartime sacrifices did not lead to the restoration of their ancestral lands by the white government:

Go, prince of Chizama's place!

You'll be eating porridge with God.

We Xhosa people never die,

We're judged when the dead arise,

death to us is profit and gain,

for there we get our strength,

for there we get our speed.

Go, Chizama, we grant you leave.

Never forget us there in the highest.

I'm finished!

I'm finished!!

I'm finished!!!'

(The Bantu World, 26 January 1935: 4; Opland, 2007: 107)

In the izibongo, the Xhosa is only 'judged when the dead arise'. This is highly ironic. The dead/ancestors never arose during the cattle-killing, as Nongqawuse had foreseen in her watery vision of the ancestors. No new herds of cattle or crops appeared; the destruction of Xhosa food-sources led only to more death (Mda, 2000: 294). This izibongo of colonialinduced and wartime loss and trauma mirrors the political milieu during the mid-1930s, and foreshadows six decades of apartheid rule. Freedom was only obtained in 1994. However, the post-apartheid challenges of South Africa are metonymic offshoots of the bodies and spirits of the Mendi fallen that are lost in the abyss of the northern seas:

There is no reaching out, no empathy

With the dead, they are alone, 
We gaze at their sea like cattle from a field

Seeing NADA, for nature is itself,

And the sea, overwhelming, metaphorless,

Delights in heaving alleluias of nameless praise

To its own mystery, or it is

A dull polder of possibilities

Where anything or nothing might happen.

(Cathal Lagan, Meditations on the Mendi, 18; Mendi: poems on the sinking of the Mendi by Cathal Lagan, Basil Somhlahlo, and Brian Walter, 1994)

Language, body and environment all conspire to form poetic bodies of ancestral remembering. These multi-sensory textual bodies are laced with the cultural-specific metonyms, metaphors and archetypes through which the ancestors are conjured. In the South African indigenous poetry, memory rings with a loud 'Ahom', which is characterised by an ambivalent experience of loss and gain.

\section{Conclusion}

The 'Ahom' with its metaphorical and metonymic traces in the indigenous poetry represents a universal apostrophe of absence. It is a modernist musical string, similar to the hollow 'boum' that resonates in the cave of E.M. Forster's A passage to India (1924). The echoes in the cave descend into a no-sound, a no-thing, and a no-language (Gillie, 1983: 145, 146). It is the ' $O$ ' in King Lear that signifies his descent into madness, emptiness and nothingness. The ' $O$ ' is the 'swollen' and 'swelling' Mendi corpse-spirits in the izibongo that are 'hovering' and 'Floating' in the 'unsteady' and 'fluid' water-cave of a strange sea (Genis, 2018: 180-182).

However, the 'Ahom' and 'boum' also signify divinity and hope. They are reminiscent of Forster's literary summons of 'OM', Brahma, the Hindu Creator in A passage to India (Gillie, 1983: 146). Forster implies the interconnectedness of absence and presence through the use of the seemingly 'nonsense' or 'no-sense' word 'boum'. Similarly, the iimbongi call on the Mendi dead through izibongo prayers to rise from the alien seabed, and to take hold of the South African consciousness because apartheid, the Adamastor-monster of their memory, has been slain. The Mendi dead's communal chorus can at last be heard as it 'rises with each wave' above the dying roar of the apartheid-Leviathan:

Six hundred plus
Young
Male
Voices
Chorus
One African
Plaintive
Hum
That rises with each wave
In harmony
With rumours of


Pharos Journal of Theology ISSN 2414-3324 online Volume 102 - Special Ed 1 (2021)

Copyright: @2021 Open Access/Author/s - Online @ http//: www.pharosjot.com

New life

Taking firm root

In the land of your birth

In alliance

With all that is young and good

And the present of peace

You bought us

With your undying love

Because we have

Rediscovered our memory

Because we have

Recovered our souls

We can now hear

These sacred voices

In all our tongues

When they pierce

Through our amnesia

Shock our consciences

Into conscious

Recall

Of every soul

Lost in these wildernesses

(Lindiwe Mabuza, The SS Mendi, 2007; Genis, 2018: 180-182)

\section{References}

Butler, G. \& J. Opland. (1989). The Magic Tree: South African Stories in Verse, Maskew Miller Longman, Cape Town.

Chapman, M, (Ed). (2002). The New Century of South African Poetry, AD Donker Publishers, Jeppestown.

Coertze, P.J. (Ed.). (1960). Inleiding tot die Algemene Volkekunde. Voortrekkerpers, Johannesburg.

Cope, J. \& U. Krige, (Eds). (1968). The Penguin Book of South African Verse, Penguin Books, Marmondsworth.

Couzens, T. \& Patel, E. (Eds). (1991). The Return of The Amasi Bird: Black South African Poetry 1891-1981, Ravan Press, Braamfontein. 
D'Abdon, R. (2016), Teaching Spoken Word Poetry as a Tool for Decolonizing and Africanizing the South African Curricula and Implementing "Literocracy", Scrutiny2: Issues in English Studies in Southern Africa, 21:2, 44-62, DOI: 10.1080/18125441.2016.1192676.

Forster, E.M. (1957). A Passage to India, Penguin Books, Harmondsworth.

Genis, G. (2019). Indigenous South African Poetry as Conduits of History: Epi-poetics - A Pedagogy of Memory, Yesterday \& Today, 22(December), 60-87, DOI: http://dx.doi.org/ $10.17159 / 2223-0386 / 2019 / \mathrm{n} 22 \mathrm{a} 4$.

Genis, G. (2018). Poetic Bodies and Corpses of War: South African Great War Poetry, Unisa Press, Pretoria.

Genis, G. (2020). Poetic Bodies: Weavings of Bodies, Languages and Environments in War Poetry by S.E.K. Mqhayi, Education as Change, 24(7961), 1-20, https://doi.org/10.25159/ 1947-9417/7961.

Gillie, C. (1983). A Preface to Forster, Longman House, Hatlow.

Grundlingh, A.M. (2011). Mutating Memories and the Making of a Myth: Remembering the SS Mendi Disaster, 1917, South African Historical Journal, 63(1, March), 20-37.

Gunner, L. (2002). A Royal Woman, An Artist, and the Ambiguities of National Belonging: The Case of Princess Constance Magogo, Kunapipi, XXIV(1-2), 205-223.

Gunner, L. (1995). Remaking the Warrior? The Role of Orality in the Liberation Struggle \& in Post-apartheid South Africa, Journal Current Writing: Text and Reception in Southern Africa, 7(2), 50-60.

Hall, M. (1987). The Changing Past: Farmers, Kings and Traders in Southern Africa, 2001860, David Philip, Cape Town.

Hodge, J. (1998). A Small History of the Body (Contribution to a Research Project: Time and the Body), Angelaki: Journal of the Theoretical Humanities, 3(3), 31-43.

Jung, C.G. (1961). Memories, Dreams, Reflections, Revised Ed, Vintage Books. (Recorded and Ed. by Jaffe, A., Tr. Winston, R. \& Winston, C.), http://www.aud.edu/files/lib2010Dec.pdf, (accessed: 16 October 2012).

Kristeva, J. (1986). Stabat Mater. In The Kristeva Reader. Moi, T. (Ed). Columbia University Press, New York.

Krog, A. (2004). The Stars Say 'Tsau', Kwela Books, Cape Town.

Lewis-Williams, D. (2004a). The Mind in the Cave: Consciousness and the Origins of Art, Thames \& Hudson, London.

Lewis-Williams, J.D. (2004b). Discovering Southern African Rock Art, Southern African Archaeology Series, David Philip, Cape Town.

Lo Liyong, T. (2018). Indigenous African literary forms may determine the future course of world literature. English in Africa, 45(2, August), 17-28.

Manathunga, C., Davidow, S., Williams, P., Gilbey, K, Bunda, T., Raciti, M. \& Stanton, S. (2020). Decolonisation through Poetry: Building First Nations' Voice and Promoting TruthTelling, Education as Change, 24(7765), 1-24, https://doi.org/10.25159/1947-9417/7765.

Mavhiza, G. \& Prozesky, M. (2020). Mapping Pathways for an Indigenous Poetry Pedagogy: Performance, Emergence and Decolonisation, Education as Change, 24(8155), 1-25, https://doi.org/10.25159/1947-9417/8155 
Maylam, P. (1989). A History of the African People of South Africa: from the Early Iron Age to the 1970s, David Philip, Cape Town.

Mda, Z. (2000). The Heart of Redness, Oxford University Press, Oxford.

Mendi: Poems on the Sinking of the Mendi by Cathal Lagan, Basil Somhlahlo and Brian Walter, (1994). Echo Poets, Alice.

Ndlovu, M.L. (2020). Dancing with Mountains. Education as Change, 24(7937), 1-20, https://doi.org/10.25159/1947-9417/7937.

Newfield, D \& Bozalek, V. (2018). A Thebuwa Hauntology, from Silence to Speech. In C.R. Kuby, K. Spector and J.J. Thiel. Posthumanism and Literacy Education: Knowing / Becoming / Doing Literacies, Routledge, New York, 37-54.

Nyamende, A. (2011). The life and times of Isaac William Wauchope (1852-1917), Quarterly Bulletin of the National Library of South Africa, 65(1/2), 4-15. Academic Search Premier, EBSCOhost. http://0-web.ebscohost.com. oasis. unisa.ac.za/ehost/pdfviewer/pdfviewer?vid= 3\&hid=7\&sid=f5d7f685-8745-4f82-833a-da4344c3a3c2\%40sessionmgr10, (accessed 21 September 2012).

Opland, J. (Ed. \& Tr.). (2009). Abantu Besizwe: Historical and Biographical Writings, 19021944, S.E.K. Mqhayi, Wits University Press, Johannesburg.

Opland J. (2004). Nineteenth-century Xhosa Literature. Kronos Southern African Histories, 30 Eastern Cape (November), 22-46, http://0-www.jstor.org. oasis.unisa.ac.za/stable/pdfplus/ 41056514.pdf? Accept TC = true, (accessed 17 August 2012).

Opland J. (2007). The First Novel in Xhosa, Research in African Literatures, 38(4, Winter), 87110. Academic Search Premier, EBSCOhost. http://0-web. ebscohost. com. oasis. unisa.ac.za/ ehost $/$ pdfviewer/ pdfviewer? vid= 5\&hid= 13\&sid= b1e73c8f-33f5-4420-ab0b771 fa699fe2a\% 40sessionmgr4, (accessed 21 September 2012).

Opland, J. (Ed.). (1992). Words that Circle Words: A Choice of South African Oral Poetry, AD Donker, Parklands.

Peires, J.B. (1987). The Central Beliefs of the Xhosa Cattle-killing, The Journal of African History, 28(1), 43-63.

Peires, J.B. (1981). The House of Phalo: A History of the Xhosa in the Days of Their Independence, Ravan Press, Johannesburg.

Saunders, C. \& Southey, N. (2001). A Dictionary of South African History. 2nd Ed, David Philip, Cape Town.

Schoeman, J.B. N.D. Psigopatologie by Tradisionele Swart Suid-Afrikaners, (Anthropology notes, UP, 1992), 448-470.

Shakespeare, W. (1947), King Lear. In The Works of William Shakespeare Gathered into One Volume, The Shakespeare Head Shakespeare, Basil Blackwell, 885-923.

The Holy Bible: Containing the Old and New Testaments. (2003). King James Version (with Concordance) 1611. A Reference Edition, Bible Society of South Africa, Cape Town.

Tracey, H. (1948). Lalela Zulu: 100 Zulu Lyrics, African Music Society, Johannesburg, (University of South Africa Library Archives: DT Cole Collection COLE0668 \& Van Schaik Collection ASC156675.)

Van der Post, L. (1961). The Heart of the Hunter. The Hogarth Press, London.

Van der Post, L. (1958). The Lost World of the Kalahari, The Hogarth Press, London. 
Pharos Journal of Theology ISSN 2414-3324 online Volume 102 - Special Ed 1 (2021)

Copyright: @2021 Open Access/Author/s - Online @ http//: www.pharosjot.com

Viljoen, L. (2006). Translation and Transformation, Scrutiny2: Issues in English Studies in Southern Africa, 11(1), 32-45, DOI: 10.1080/18125441.2006.9684200.

Zarwan, J. (1976). The Xhosa Cattle-killings, Cahiers d'etudes africaines, XVI(63-64), 519539. 